\title{
EWSR1/ERG Fusion Gene
}

National Cancer Institute

\section{Source}

National Cancer Institute. EWSR1/ERG Fusion Gene. NCI Thesaurus. Code C99211.

A fusion gene that results from a chromosomal translocation $\mathrm{t}(21 ; 22)(\mathrm{q} 21 ; \mathrm{q} 12)$ which fuses the EWSR1 gene with the ERG gene. This rearrangement is associated with both Ewing tumor/peripheral primitive neuroectodermal tumor and desmoplastic small round cell sarcoma. 